Revta brasil. Bot., São Paulo, V.23, n.2, p.113-120, jun. 2000

\title{
Development, structure and distribution of colleters in Mandevilla illustris and M. velutina (Apocynaceae)
}

\author{
BEATRIZ APPEZZATO-DA-GLÓRIA ${ }^{1,3}$ and MARIA EMÍLIA MARANHÃO ESTELITA²
}

(received: March 31, 1999; accepted: December 20, 1999)

\begin{abstract}
Development, structure and distribution of colleters in Mandevilla illustris and M. velutina (Apocynaceae)). Colleters of Mandevilla illustris and M. velutina are present on the cotyledons, shoot apices, mature leaves and on the nodal region, where they are interpetiolar and intrapetiolar. In M. velutina there are two colleters on the adaxial basal part of the leaf blade, and in M. illustris, this number varies. The differentiation of the colleters occurs in the early stages of leaf development. When colleters are mature, they consist of a long head on a short stalk. The central core of the colleter is made up of parenchymatous cells that may exhibit phenolic compounds and is surrounded by radially elongated epithelial cells. The foliar and intrapetiolar colleters can exhibit vascularization. The colleters produce a translucient sticky substance that reacts positively to polysaccharides and, before senescence, they produce lipophilic substances. The Mandevilla colleters data can give support to the taxonomy and phylogeny of the Apocynaceae.
\end{abstract}

RESUMO - (Desenvolvimento, estrutura e distribuição de coléteres em Mandevilla illustris e M. velutina (Apocynaceae)). Coléteres de Mandevilla illustris e M. velutina estão presentes nos cotilédones, ápices caulinares, folhas maduras e na região nodal, onde estes são interpeciolares e intrapeciolares. Em M. velutina existem dois coléteres na face adaxial da base da lâmina foliar, porém, em $M$. illustris este número varia. A diferenciação dos coléteres ocorre nos estágios iniciais do desenvolvimento foliar. Quando os coléteres estão maduros, eles consistem de uma longa cabeça sobre um curto pedúnculo. A porção central do coléter é constituída de células parenquimáticas que podem apresentar compostos fenólicos e é envolvida por células epiteliais radialmente alongadas. Os coléteres foliares e intrapeciolares podem exibir vascularização. Os coléteres produzem uma substância pegajosa e translúcida que reage positivamente para polissacarídeos e, antes da senescência, eles produzem substâncias lipofílicas. As informações obtidas sobre os coléteres das Mandevilla podem fornecer subsídios aos estudos taxonômicos e filogenéticos das Apocynaceae.

Key words - Colleters, Mandevilla, Apocynaceae, anatomy, ontogeny

\section{Introduction}

The secretory structures, termed colleters, are found on the adaxial side of different organs in a large number of angiosperm families (Thomas 1991).

Even though the colleters are a characteristic feature of the Apocynaceae family only few studies have been done (Thomas et al. 1989). A comparative and phylogenetic significance of colleters of 19 members of the Apocynaceae was studied on the basis of both morphological and anatomical characters (Thomas \& Dave 1991). Colleters have taxonomic significance to the Mandevilla genus on the basis of their number and position where they are attached (Woodson 1933, Woodson \& Moore 1938).

1. Departamento de Ciências Biológicas, Escola Superior de Agricultura 'Luiz de Queiroz', Universidade de São Paulo, Caixa Postal 09, 13418-900 Piracicaba, São Paulo, Brasil.

2. Departamento de Botânica, Instituto de Biociências, Universidade de São Paulo, Caixa Postal 11461, 05422-970 São Paulo, Brasil.

3. Corresponding author: bagloria@carpa.ciagri. usp.br
There is no detailed study on the structure, development and secretion of the colleters of Mandevilla illustris and M. velutina, two herbaceous species from Brazilian savannas. Therefore, the present investigation describes these aspects emphasizing the taxonomic and phylogenetic significance of the colleters.

\section{Material and methods}

Shoot apices with the outermost primordium measuring 4-8 $\mathrm{mm}$ length, leaves with $2-5 \mathrm{~cm}$ and $8-10 \mathrm{~cm}$ length and cotyledonary leaves with $1 \mathrm{~cm}$ length of Mandevilla illustris (Vell.) Woodson and M. velutina (Mart. ex Stadelm.) Woodson were collected from savanna (Cerrado) area at the Experimental Station of Itirapina, São Paulo State, Brazil. The identified specimens are deposited in Escola Superior de Agricultura Luiz de Queiroz (ESA) Herbarium: ESA 6120; ESA 6271; ESA 7037; ESA 7089.

The material was fixed in FAA 50 (Sass 1951) for costumary methods of paraffin embedding, sectioning and mounting of histological sections. Transverse and longitudinal serial sections, 6-8 $\mu \mathrm{m}$ thick, were stained with safranin and fast green (Sass 1951).

Leaves and shoot apices were fixed in Farmer-Carnoy modified by Berlyn \& Miksche (1976), dehydrated in an ethanol series, dried to the critical point, mounted on aluminum stubs and sputter-coated with 30-40 nm of gold. Observations and micrographs were made with a Philips SEM 505 scanning electron microscope at $12.5 \mathrm{kV}$. 
For histochemistry tests, sections of the shoot tips and leaves at different growing phases were stained in ruthenium red for polysaccharides (Johansen 1940), Sudan black B for fatty substances (Jensen 1962). Tannic substances were detected by ferric chloride (Johansen 1940), starch and cellulose were identified by the use of iodide zinc cloride (Strasburger 1913). Phloroglucinol and $\mathrm{HCl}$ were used to detect lignification (Johansen 1940).

\section{Results}

In both Mandevilla species examined, the colleters are differentiated into a long head on a short stalk. They are found on the apical bud (figures 1-2), adaxial basal part of petiole, leaf blade (figure 3 ) and cotyledons (figure 5). The colleters are interpetiolar (figures 1 and 4) and intrapetiolar (figure 3). There are two different sizes of colleters on the last position (figure 4). The shorter one measures $300-400 \mu \mathrm{m}$ in length and $170 \mu \mathrm{m}$ in width at the broader region. The longer one measures 500-600 $\mu \mathrm{m}$ in length and $250 \mu \mathrm{m}$ in width at the broader region. In spite of this difference, the mode of development and secretion follows the same pattern. In M. velutina there are always two colleters on the adaxial basal part of the leaf blade (figure 3) but, in M. illustris, this number is higher and variable.

Internally, all colleters consist of a central core of parenchymatous cells surrounded by radially elongated epithelial cells, covered externally by a cuticle (figures 6-9). In some transversal sections, there are two small cells which are different in shape from the others and form a slight depression on the colleter surface (figure 10). Some central parenchyma cells react positively to tannin and fatty substances tests. Frequently, there are non-articulated and branched laticifers in this region (figure 21). Foliar and intrapetiolar colleters can or not be vascularized (figure 9) depending on their proximity to the organs vasculature they are attached. In $M$. illustris the number of vascularized colleters is higher than in M. velutina. The interpetiolar colleters lack vascularization.

The primordia colleters consist of protoderm and subtending ground meristem (figures 13-20) and appear at the base of the leaf adaxial surface when it is about $1000 \mu \mathrm{m}$ long. The primordial cells are distinctive from the adjacent ones in having relatively dense cytoplasm (figure 13). The protoderm cells divide anticlinally, while those of the ground meristem divide in many planes, particularly in periclinal ones (figures 14-17). Consequently, the primordium becomes elongated and grows upward, parallel to the leaf where it was borne (figure 18). During the head differentiation, the ground cells elongate axially and the epidermal cells divide through rapid anticlines. The stalk differentiation begins in the basal region with rapid periclines in the ground cells and anticlines in the protoderm cells (figure19).

Before the secretory stage, the epithelial cells are approximately rectangular, have thin walls and dense cytoplasm appressed close the walls. When secretion starts, some epithelial cells undergo an outer pericline wall protrusion followed by withdrawal of the anticline walls (figures 8 and 10) reaching a claviform shape. In paradermal section there are small vertical intercellular channels at the joins of three or four adjacent cells. These intercellular channels results from the dissolution of middle lamellae along the radial walls of epithelial cells. At this stage, it is observed a withdrawal of the cytoplasm along the radial and the outer tangential walls (figures 8 and 10). The cuticle becomes separated in certain regions forming a subcuticular space (figure 10). Before and during secretion, the epithelial cells content reacts to polysaccharides.

The foliar colleters attain maturity and become secretory before leaf get a length of $2 \mathrm{~cm}$ (figure 7). The secretion is in the peak period before the opening and spreading of the leaves that covers the apical bud. When young, colleters are green, very active and secrete a colorless and viscous fluid (figure 2). However, lipid globules are accumulated in large quantities in the epithelial cells (figure 11) before the senescence phase (figure 12). After ceasing its secretory function, the colleter senesces, with a gradual colour change from green to dark-brown. This alteration proceeds until the foliar maturation $(8-10 \mathrm{~cm}$ in length). The lignification starts at the epithelium and proceeds centripetally and basipetally. The colleters are persistent.

\section{Discussion}

Many Apocynaceae genera are characterized by colleters on the adaxial face of the leaves, on leaf modificated as bract, on bracteole and calix and on the nodal region (Ezcurra 1981). Studies 
concerning the occurrence of colleters on cotyledonary leaves are rare. It was described only for Nerium by Williams et al. (1982) and for Mandevilla in the present study. The most prob-
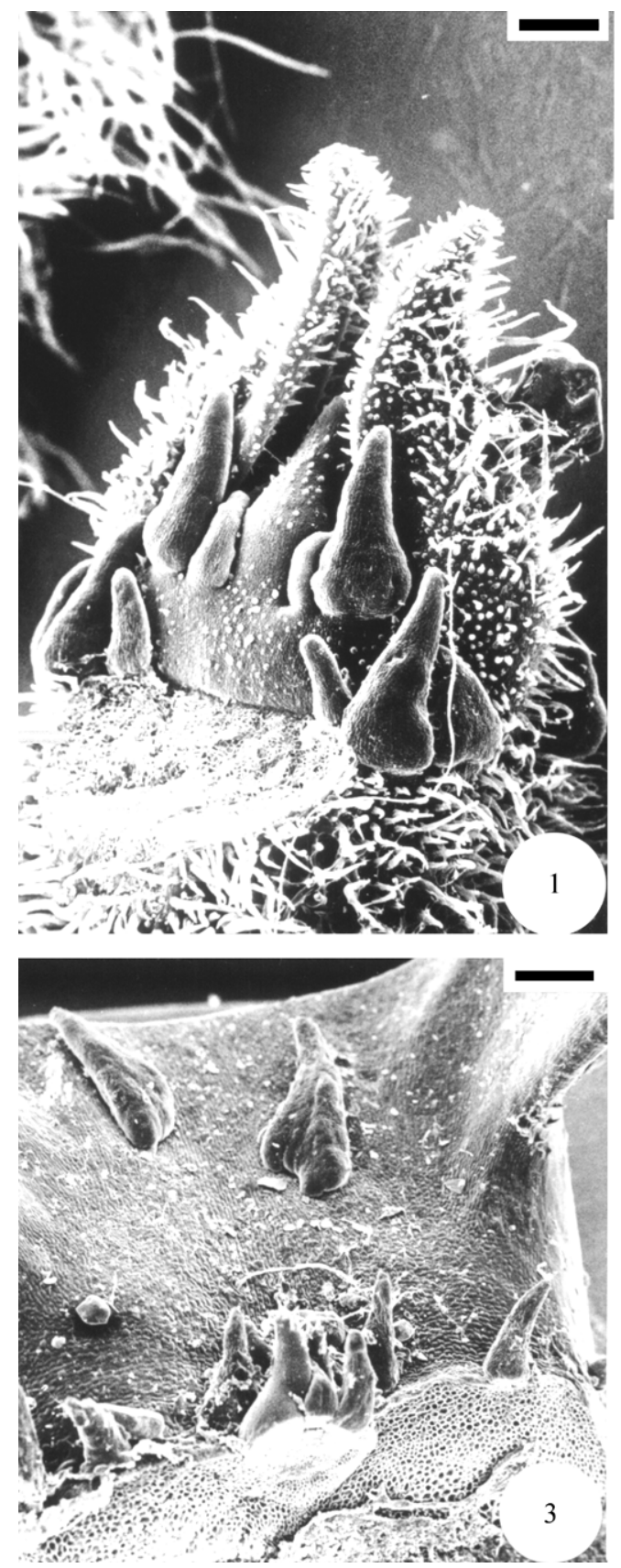

ably reason to this fact is that seedlings have not been analysed.

The ontogeny of colleters on both Mandevilla species follows the same pattern as verified in Allamanda
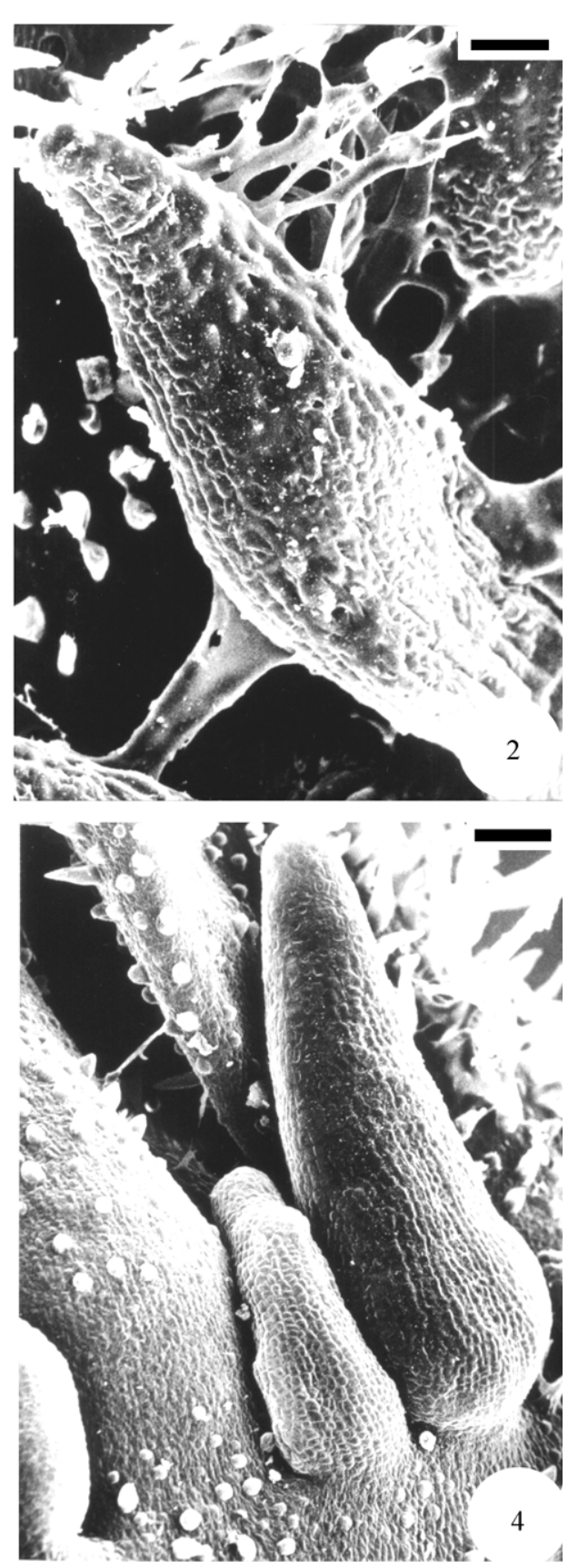

Figures. 1-4. SEM micrographs of Mandevilla colleters. 1. Apical bud of M. illustris showing the interpetiolar colleters. Bar $=130 \mu \mathrm{m}$. 2. Colleter of M. illustris during the active secretory phase. Bar $=38 \mu \mathrm{m}$. 3. Two colleters on the adaxial basal part of the leaf blade of Mandevilla velutina. Bar $=180 \mu \mathrm{m}$. 4 Interpetiolar colleters of $M$. illustris (note the size difference). Bar $=38 \mu \mathrm{m}$. 
(Ramayya \& Bahadur 1968) and in Nerium (Thomas \& Dave 1989a). These confirmed the Ramayya and Bahadur's view that colleters cannot be regarded as hair structures, as reported by Solereder (1908), because they developed from both protoderm and ground elements.

The colleters produce frequently a mixture of terpenes and mucilage (Esau 1965). The Mandevilla colleters secrete a colorless and viscous fluid that reacts to polysaccharides and before senescence their epithelial cells also accumulate lipid globules.

In both Mandevilla species, the colleters are of the 'standard type' (S) described by Lersten (1974). In Aganosoma (Dave et al. 1987) and in Allamanda (Thomas \& Dave 1989a) the development of the

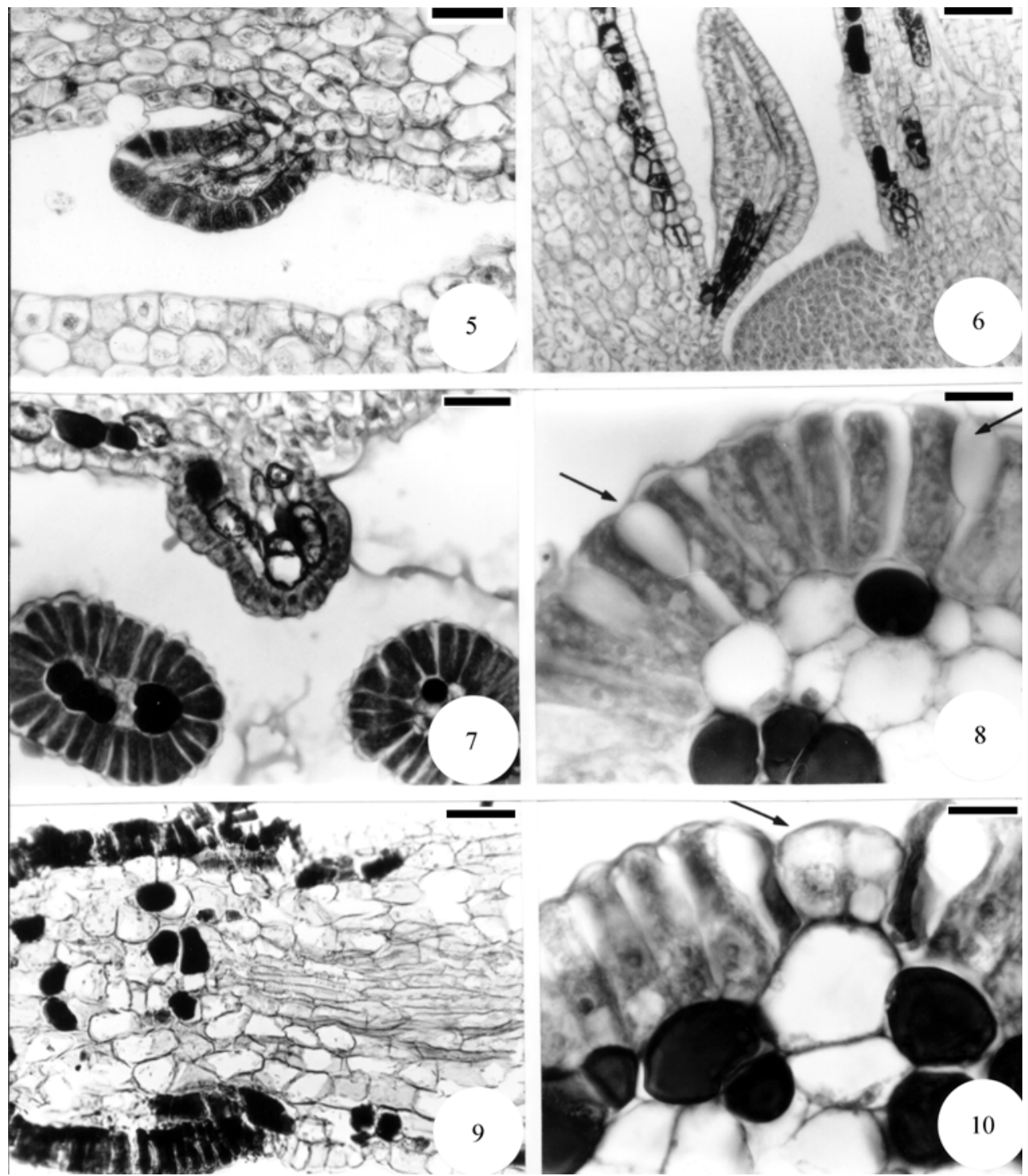

Figures 5-10. Transverse (T.S.) and longitudinal (L.S.) sections of Mandevilla illustris colleters. 5. Colleter on adaxial face of the cotyledonary leaf. Bar $=100 \mu \mathrm{m}$. 6. Intrapetiolar colleter during differentiation. Bar $=100 \mu \mathrm{m}$. 7. Intrapetiolar colleters during their secretory phase. $\mathrm{Bar}=100 \mu \mathrm{m}$. 8. T.S. of the colleter during secretion showing the outer pericline walls protruded and the withdrawal of the anticline walls (arrow). Bar $=50 \mu \mathrm{m}$. 9. Vascularized intrapetiolar colleter in L.S. Bar $=200 \mu \mathrm{m}$. 10. T.S. of the colleter showing tanniferous idioblasts and two epithelial cells different in size and shape from the others and which form a slight depression on the colleter surface (arrow). Bar $=50 \mu \mathrm{m}$. 


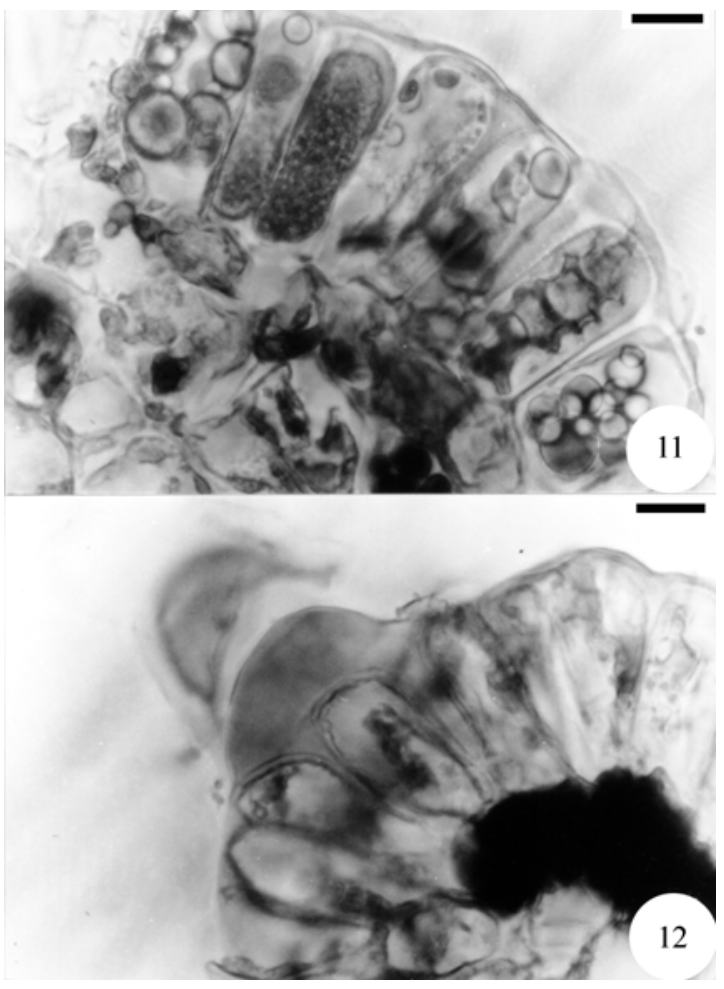

Figures. 11-12. Epithelial cells of the Mandevilla illustris foliar colleters (11) with lipid globules which disappear on the senescence phase (12). Bar $=4 \mu \mathrm{m}$.

epithelial cells is not uniform as observed in the present study. In Mandevilla colleters there are tanniferous idioblasts and laticifers among their parenchymatous cells. Tanniferous idioblasts were also observed in colleters of Himatanthus (Barros 1986/88) and laticifers have been reported in Plumeria (Murugan \& Inamdar 1987a), Vallaris (Murugan \& Inamdar 1987b), Allamanda (Thomas \& Dave 1989b), and Nerium (Thomas \& Dave 1989b).

Vascularized colleters have been reported in Strophanthus and Funtumia (Woodson \& Moore 1938), Holarrhena, Vallaris and Wrightia (Rao \& Ganguli 1963) and Aganosoma (Dave et al. 1987). According to Williams et al. (1982), the colleters on the adaxial face of the petioles of Nerium have no vascular traces. But Thomas \& Dave (1989 b) reported vascularized calycine colleters in Nerium.

The vasculature in a structure is directly proportional to its size and it is not necessarily related to any state of development (Carlquist 1969). In both
Mandevilla species, the observations are not in accordance with the Carlquist's proposition. Independently of its size the interpetiolar colleters always lack vascularization and the foliar and the intrapetiolar colleter can or not be vascularized. Arekal \& Ramakrishna (1980) also contested Carlquist's view (1969) because larger nectaries of Calotropis are devoided of vasculature and smaller ones of Wattakaka have traces. Vasculature in the colleter is always connected to the organ to which it is attached (Thomas 1991). In fact, in Mandevilla, the presence of vascularization seems to depend on the proximity of the colleter to the vascular traces of the organ where it is attached. In the present study, it is also observed that is necessary to analyse the colleters in transverse and longitudinal serial sections because depending on the plane of section, the vascular tissue can be verified or not. Probably, for this reason Dave et al. (1987) reported only a few colleters with vascularization in Aganosoma, while Rao \& Ganguli (1963) described them as non-vascularized.

Either vascular tissue or laticifers and secretory idioblasts appear in the colleter. These structural modifications in Mandevilla are considered an evolutionary step among the colleters of Apocynaceae (Thomas 1991).

Woodson \& Moore (1938) emphasized the taxonomic significance of the colleters in Apocynaceae on the basis of their number, arrangement and distribution pattern. In the present study, the number of the colleters at the adaxial base of the lamina is suitable for anatomical diagnose.

According to Thomas (1991), colleters start to secrete prior to the expansion of the leaf where they are attached as observed in the present study. At this stage, Mandevilla colleters are green and exude a sticky material which completely coats the shoot apex. However, Fjell (1983) could not found any secretion from the colleters of Vinca.

The dissolution of middle lamellae along the radial walls of epithelial cells, the formation of a gap, and the release of the secretory product into the gap, are interesting features exhibited by epithelial cells in the colleters of both Mandevilla species and in those of Plumeria (Mohan \& Inamdar 1986). According to Dave et al. (1988), the formation of a gap by the withdrawal of the cytoplasm in the epithelial cells along the radial walls speeds up the process of secretion. 
The same was described for Azadirachta by Inamdar et al. (1986) and was observed for both Mandevilla species during the secretion of the lipophilic substances.

The epithelial cells react positively for starch and mucilage at the pre-secretory and secretory stages. At the post-secretory phase the epithelial cells show many lipid globules. In Allamanda, the quantity of lipid globules is maximum in younger colleters, but the lipid disappear in later stages of the colleter development (Thomas \& Dave 1989a). In Plumeria, Mohan \& Inamdar (1986) verified a continuous production of lipids in all stages of the colleters development.

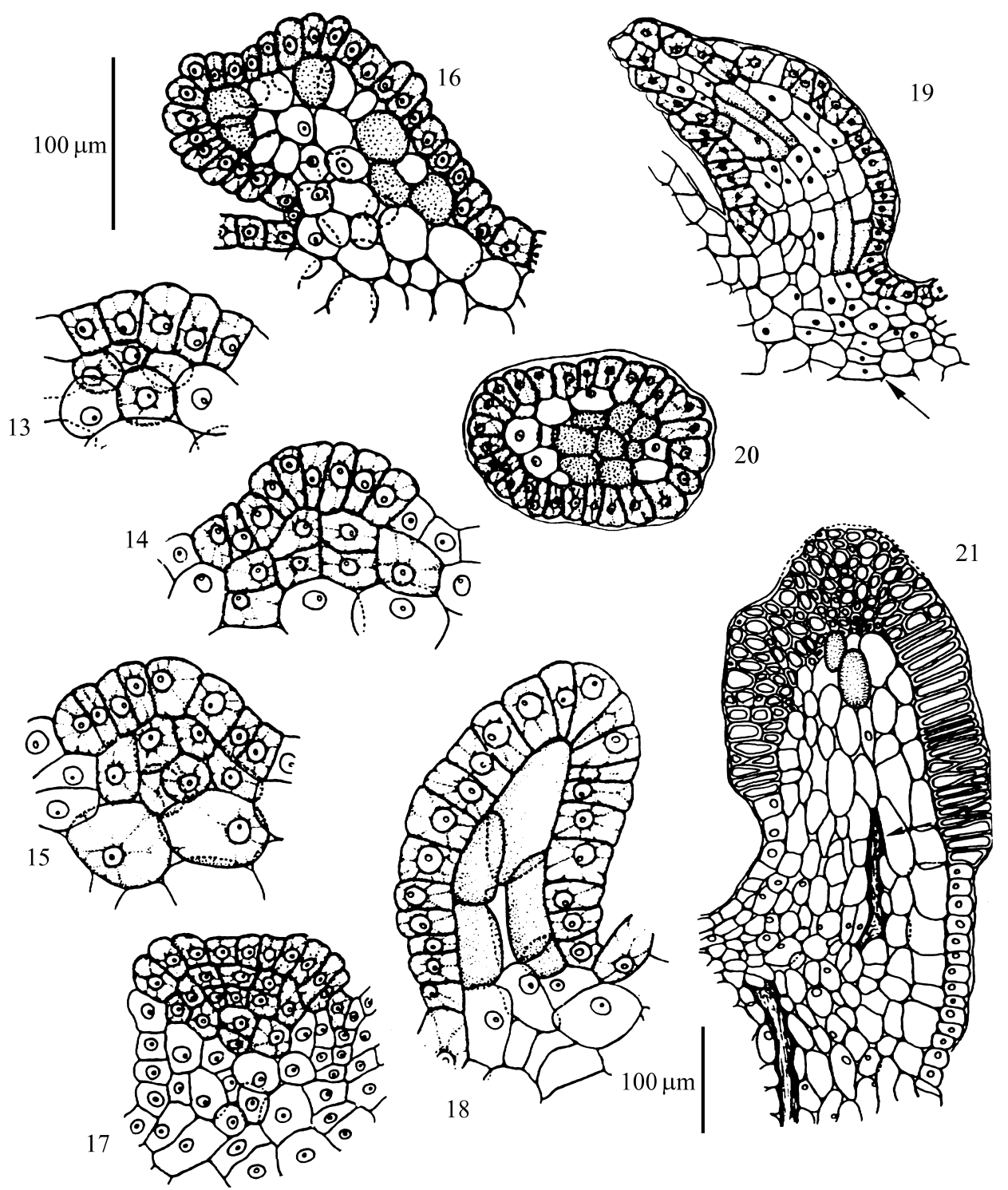

Figures. 13-21. Diagrammatic representation of the sucessive developmental stages of Mandevilla illustris colleter. 13. The primordial cells are distinct from the adjacent ones due to their dense cytoplasm. 14-15. The protoderm cells divide anticlinally and the subprotoderm cells divide periclinally. 16-18. The primordium becomes elongated and grows upward. 19. The arrow indicates the division of the initial cells during stalk differentiation. 20. Transverse section of the colleter showing gaps between central cells. 21. Mature colleter showing laticifers among parenchyma cells (arrow). 
The protective function of the colleter has been well established in many Apocynaceae (Thomas \& Dave 1989 a, b). According to Dell (1977), besides the protective role against herbivores and pathogens, the resinous coating may help to reduce water loss by cuticular transpiration in the warm tropical climates. The same mechanism of protection could be attribute to the Mandevilla colleters since the species grow in Brazilian savannas and the secretory period is just before the opening and spreading of the leaves which cover the apical bud. Besides the protection of the shoot apices, the colleters may effectively inhibit the growth of axillary buds in Nerium and thus govern the apical dominance in vegetative shoots (Williams et al. 1982). The vegetative dominance was also verified in Mandevilla in the present study.

After ceasing its secretory function, the Mandevilla colleters start to senesce with a gradual colour change from green to brown (Kuriachen \& Dave 1989, Thomas et al. 1989).

In colleters of Mandevilla the process of senescence initiate at the apex by wall thickening and cytoplasm degeneration and it proceed basipetally. This is in accordance with the observations made in colleters of Aganosoma and Gardenia (Dave et al. 1987, 1988), Calotropis (Kuriachen \& Dave 1989), Roupelia (Thomas et al. 1989).

According to Esau (1965), colleters wither away after ceasing their secretory function. But in Apocynaceae, calycine colleters are persistent (Thomas 1991). Persistent petiolar colleters also occur in Allamanda (Thomas \& Dave 1989a) and in Mandevilla we studied.

Acknowledgements - We thank to Fundação de Amparo à Pesquisa do Estado de São Paulo (FAPESP) for the financial support and to professor Yedo Alquini, from the Botany Department and Microscopic Centre of the Federal University of Parana, Brazil for facilities in the electron microscope analyses.

\section{References}

AREKAL, G.D. \& RAMAKRISHNA, T.M. 1980. Extrafloral nectaries of Calotropis gigantea and Wattakaka volubilis. Phytomorphology 30:303-306.

BARROS, C.F. 1986/88. Himatanthus lancifolius (Muell-Arg.) Woodson (Apocynaceae): Anatomia foliar. Rodriguésia 64/66:25-31.
BERLYN, G.P. \& MIKSCHE, J.P. 1976. Botanical microtechnique and cytochemistry. Iowa State University Press, Ames.

CARLQUIST, S. 1969. Toward acceptable evolutionary interpretations of floral anatomy. Phytomorphology 19:332-362.

DAVE, Y., THOMAS, V. \& KURIACHEN, P.M. 1987. Structure and development of colleters in Aganosoma caryophyllata G. Don. Pakistan Journal of Botany 19:243-248.

DAVE, Y., KURIACHEN, P.M. \& THOMAS, V. 1988. Development, structure and senescence of colleters in Gardenia lucida Roxb. (Rubiaceae). Acta Societatis Botanicorum Polonie 57:3-7.

DELL, B. 1977. Distribution and function of resin and glandular hairs in Western Australian Plants. Journal of Proceedings of the Royal Society of Western Australia 59:119-123.

ESAU, K. 1965. Plant Anatomy. 2 ed. John Wiley, New York.

EZCURRA, C. 1981. Revisión de las Apocinaceas de la Argentina. Darwiniana 23:367-474.

FJELL, I. 1983. Anatomy of xeromorphic leaves of Allamanda neriifolia, Thevetia peruviana and Vinca minor (Apocynaceae). Nordic Journal of Botany 3:383-392.

INAMDAR, J.A., SUBRAMANIAN, R.B. \& MOHAN, J.S.S. 1986. Studies on the resin glands of Azadirachta indica A. Juss. (Meliaceae). Annals of Botany 58:425-429.

JENSEN, W.A. 1962. Botanical histochemistry. W.H. Freeman., San Francisco.

JOHANSEN, D.A. 1940. Plant microtechnique. McGraw-Hill Company Inc, San Francisco.

KURIACHEN, P.M. \& DAVE, Y. 1989. Structural development and histochemical studies in the colleters of Calotropis L. (Asclepiadaceae). Journal of Phytological Research 2:7-14.

LERSTEN, N.R. 1974. Morphology and distribution of colleters and crystals in relation to the taxonomy and bacterial leaf nodule symbiosis of Psycotria (Rubiaceae). American Journal of Botany 61:973-981.

MOHAN, J.S.S. \& INAMDAR, J.A. 1986. Ultrastructure and secretion of extrafloral nectaries of Plumeria rubra L. Annals of Botany 57:389-401.

MURUGAN, V. \& INAMDAR J.A. 1987a. Organographic distribution, structure and ontogeny of laticifers in Plumeria alba Linn. Proceedings of Indian Academy of Sciences, 97:25-31.

MURUGAN, V. \& INAMDAR J.A. 1987b. Studies in the laticifers of Vallaris solanaceae. Phytomorphology 87:209-14.

RAMAYYA, N. \& BAHADUR, B. 1968. Morphology of the "squamellae" in the light of their ontogeny. Current Science 37:520-522.

RAO, V.S. \& GANGULI, A. 1963. Studies in the floral anatomy of the Apocynaceae. Journal of the Indian Botanical Society 42:419-435.

SASS, J.E. 1951. Botanical microtechnique. Iowa State University Press, Ames.

SOLEREDER, H. 1908. Systematic anatomy of the Dicotyledons. Clarendon Press, Oxford.

STRASBURGER, E. 1913. Handbook of pratical botany. George Allen and Company Ltda., London. 
THOMAS, V. 1991. Review Article. Structural, functional and phylogenetic aspects of the colleter. Annals of Botany 68:287-305.

THOMAS, V., DAVE, Y. \& MENON, A.R.S. 1989. Anatomy and histochemistry of colleters in Roupelia grata (Apocynaceae). Nordic Journal of Botany 8:493-496.

THOMAS, V. \& DAVE, Y. 1989a. Structure, origin, development and senescence of colleters in Nerium indicum Mill. (N. odorum Soland., Apocynaceae). Korean Journal of Botany 32:163-172.

THOMAS, V. \& DAVE, Y. 1989b. Histochemistry and senescence of colleters of Allamanda cathartica (Apocynaceae). Annals of Botany 64:201-203.
THOMAS, V. \& DAVE, Y. 1991. Comparative and phylogenetic significance of the colleters in the family Apocynaceae. Feddes Repertorium 102:177-182.

WILLIAMS, R.F., METCALFE, R.C. \& GUST, L.W. 1982. The genesis of form in oleander (Nerium oleander L.). Australian Journal of Botany 30:677-687.

WOODSON, R.E. JR. 1933. Studies in the Apocynaceae IV: The american genus of Echitoideae. Annals of the Missouri Botanical Garden 20:605-627.

WOODSON, R.E. JR \& MOORE, J.A. 1938. The vascular anatomy and comparative morphology of apocynaceous flowers. Bulletin of the Torrey Botanical Club 65:135-166. 